Original research article

\title{
Cholesterol and glucose profiles according to different fasting C-peptide levels: a cross-sectional analysis in a healthy cohort from the Czech Republic
}

\author{
Vladimír Kron ${ }^{1,4,6}$ *, Miroslav Verner ${ }^{2,5}$, Ladislav Pešl ${ }^{3}$, Pavel Smetana ${ }^{1}$, Jaromír Kadlec ${ }^{1}$, \\ Daniel Martiník ${ }^{4}$ \\ ${ }^{1}$ University of South Bohemia, Faculty of Agriculture, Department of Food Biotechnologies and Agricultural Products Quality, České Budějovice, \\ Czech Republic \\ ${ }^{2}$ Hospital of České Budějovice, a. s., Central Laboratories, České Budějovice, Czech Republic \\ ${ }^{3}$ Hospital of České Budějovice, a. s., Cardiovascular and Thoracic Center, České Budějovice, Czech Republic \\ ${ }^{4}$ Clinic for Metabolic Assessment of prof. MUDr. Karel Martiník, DrSc., s.r.o., Hradec Králové, Czech Republic \\ ${ }^{5}$ University of South Bohemia, Faculty of Health and Social Sciences, Institute of Laboratory Diagnostics, České Budějovice, Czech Republic \\ ${ }^{6}$ University of South Bohemia, Faculty of Science, Department of Medical Biology, České Budějovice, Czech Republic
}

\section{Abstract}

The relationship between glycaemia and lipoprotein metabolism has not been completely clarified, and slight differences may be found between local authors, trials and evaluated parameters. Therefore this cross-sectional study investigated fasting cholesterol and glucose levels along with the determination of atherogenic index in a cohort of healthy individuals from the Czech Republic in relation to their fasting C-peptide levels. Data were collected between 2009 and 2018 and a total of 3189 individuals were stratified by C-peptide reference range $(260-1730 \mathrm{pmol} / \mathrm{l})$ into three groups - below $(n=111)$, within $(n=2952)$ and above $(n=126)$. Total, HDL, LDL cholesterol and atherogenic index were used to compare lipoprotein levels by relevant $C$-peptide concentrations. Participants using the supplements to affect lipid or glycaemia metabolism were excluded from this study. The evaluation of blood parameters in a fasting state included correlations between $C$-peptide and cholesterols, differences of variances ( $F$-test) and the comparison of lipoprotein mean values ( $t$-test) between the groups created by the C-peptide reference range. Mean values of total (4.9, 5.1, $5.3 \mathrm{mmol} / \mathrm{l}), \mathrm{LDL}$ (2.6, 3.1, 3.4 mmol/l) cholesterol and atherogenic index $(2.1,2.8,3.7)$ were higher with increasing C-peptide levels, whereas HDL was inversely associated with fasting C-peptide concentration. A positive and negative correlation between atherogenic index $\left(r_{\mathrm{xy}}=0.36\right)$ and HDL level $\left(r_{\mathrm{xy}}=-0.36\right)$ with C-peptide values was found. Differences of HDL, LDL and atherogenic index were, in particular, recorded between the groups below and above the reference range of $C$-peptide $(p \leq 0.001)$. Considerable differences $(p \leq 0.001)$ were also observed for the same lipoprotein characteristics between the groups above and within the $\mathrm{C}$-peptide reference. Generally, the type of cholesterol is crucial for the evaluation of specific changes concerning the $C$-peptide range. Lipoprotein concentrations differ in relation to $C$-peptide - not only below and above the physiological range, but also inside and outside of it.

Conclusions: Fasting levels of cholesterol, plasma glucose, and atherogenic index were strongly associated with fasting C-peptide levels in healthy individuals. Our data suggest that fasting C-peptide could serve as a biomarker for the early detection of metabolic syndrome and/or insulin resistance prior to the manifestation of type 2 diabetes.
\end{abstract}

Keywords: Atherogenic index; C-peptide; Cholesterol; HDL; LDL; Lipoprotein

\section{Highlights:}

- Metabolic syndrome and insulin resistance seem to be associated with the changes in lipoprotein profiles and other biomarkers.

- Elevated or decreased C-peptide levels are a useful surrogate for the presence of metabolic syndrome and insulin resistance.

- In a cohort of healthy individuals from the Czech Republic, total, LDL and HDL cholesterol as well as atherogenic index were strongly associated with fasting C-peptide levels above the upper limit of the reference range of $1730 \mathrm{pmol} / \mathrm{l}$.

- Compared to individuals with lowest fasting C-peptide ( $<260 \mathrm{pmol} / \mathrm{l})$, total, LDL and atherogenic index were significantly increased in normal reference fasting C-peptide group or above, whereas HDL cholesterol was inversely correlated with increasing C-peptide levels.

- Fasting C-peptide could serve as a biomarker for the early detection of metabolic syndrome and/or insulin resistance in healthy individuals who are at elevated risk of atherosclerosis prior to the manifestation of type 2 diabetes.

- These results in healthy individuals confirm previous findings from other populations and support fasting C-peptide to be a valuable diagnostic biomarker in routine clinical practice.

- Fasting C-peptide is a suitable parameter for primary and secondary prevention of metabolic disorders.

Abbreviations: HDL - high density lipoprotein; LDL - low density lipoprotein

\footnotetext{
* Corresponding author: Vladimír Kron, Clinic for Metabolic Assessment of prof. MUDr. Karel Martiník, DrSc., s.r.o., Bratří Štefanů 895, 50003 Hradec Králové, Czech Republic; e-mail: vladimir.daniel.kron@gmail.com http://doi.org/10.32725/jab.2021.023

Submitted: 2021-02-01 • Accepted: 2021-09-24 • Prepublished online: 2021-10-13

J Appl Biomed 19/4: 220-227 • EISSN 1214-0287 • ISSN 1214-021X

(c) 2021 The Authors. Published by University of South Bohemia in České Budějovice, Faculty of Health and Social Sciences.

This is an open access article under the CC BY-NC-ND license.
} 


\section{Introduction}

C-peptide has been evaluated as an important parameter of effective insulin secretion. Some authors have determined the assessment of C-peptide as a cornerstone of basic analysis in normally glucose tolerant patients too, because it could reveal adverse insulin secretion and glycaemia changes. Consequently, repeated detections of $C$-peptide can be used for nutritional corrections during the management of therapy (Leighton et al., 2017).

An important trait of C-peptide is higher metabolic stability in comparison to the insulin. The degradation rate of $C$-peptide in the body is slower and thus affords a more balanced testing window of beta cell functionality (Yosten et al., 2014). Furthermore, administered exogenous insulin does not affect C-peptide levels and therefore reliably reflects its original secretion (Jones and Hattersley, 2013; Kulkarni and Patil, 2016). Except for direct consideration of insulin secretion and glycaemia, C-peptide has already been considered in the relationship to nerve, kidney, cardiovascular functions and lipid metabolism (Hirai et al., 2008; Pickens et al., 2016).

Because the mechanism of C-peptide acting on lipoproteins remains partially unclear, some trials have aimed to reveal the association between serum $C$-peptide and the lipoproteins (Rebsomen et al., 2008). To test this hypothesis, Li et al. (2015) compared HDL concentrations by different quartiles of $\mathrm{C}$-peptide in the individuals without diabetes. The results confirmed a possible relationship between HDL and C-peptide, and recommended the analysis of $\mathrm{C}$-peptide as an important factor of cardiovascular diseases. C-peptide, cholesterols and triglycerides concentrations in non-diabetic patients have also been linked with other metabolic and body parameters (e.g. obesity characteristics) (Andrade et al., 2018). Gradually, C-peptide values have come to be considered as crucial for possible correlation with the circumstances of cardiovascular diseases (Harnishsingh and Rama, 2018).

On the other hand, some trials have remained ambiguous due to unclear mechanism between glycaemia and lipoprotein parameters. No association was recorded in the study of Wahab et al. (2018), including insulin and C-peptide levels with regards to cardiovascular incidence after the consideration of other risk factors. Similarly, no correlation was also found between $\mathrm{C}$-peptide and cardiovascular mortality after the adjustments linked with lipid (HDL cholesterol, triglycerides) and glycaemia parameters (Bo et al., 2012).

However, the anti-lipolytic and vasodilator effects of C-peptide suggest that they may contribute to the finetuning of metabolic tissues under different physiological conditions and thus should not be underestimated (Andrade et al., 2018; Min and Min, 2013). The fact that such a small number of studies have shown the relationship between C-peptide and metabolic cardiovascular risk factors suggest a need to analyze this principle (Ghorbani and Shafiee-Nick, 2015).

\section{Material and methods}

\section{Patient and sample distribution}

Metabolic profiles of correlative study were collected in the Czech Republic from 2009 to 2018. All participants gave their consent to anonymous data analysis. The evaluation didn't prefer any subjects under special, social, cultural fitness conditions. The patients included were aged $18-78(n=3189)$ to get an optimal profile of the population. Generally, the patients with the diagnoses or specific therapy that could affect investigated parameters were excluded. This limitation also included the supplements to affect insulin, glucose or lipid concentrations. After summaries of information on the subjects had been prepared, they were properly processed (centrifuging, serum preparation, etc.) and analyzed. All samples were taken in an overnight fasting state (minimum of 8 hours) to test basal metabolism.

\section{Laboratory analysis}

All serum and plasma biochemical parameters were determined from venous blood. $C$-peptide and insulin concentrations were analyzed by regulatory impact assessment methodology from the plasma with the use of immunochemical methods. Glucose concentrations were measured enzymatically as well as total cholesterol (enzymatic assays). Homogeneous methods were used for the detection of HDL and LDL in auto-analyzers. All biochemical parameters for tests were provided by the instructions of manufacturers (Roche Diagnostics, Abbott Laboratories) with a strict following of the measurement continuity. The same methodology has been used for the testing of the relationship between C-peptide and glycated haemoglobin, insulin and glucose in non-diabetic patients (Khan et al., 2018; Mathews et al., 1985; Pozzan et al., 1997).

\section{Parameters for evaluation}

The reference range of C-peptide (260-1730 pmol/l) was adapted to the Czech Republic (Methodology of C-peptide..., 2020). Different units of $C$-peptide concentrations were re-calculated using the following rules $(1 \mathrm{nmol} / 1=1 \mathrm{pmol} / \mathrm{ml}=$ $1000 \mathrm{pmol} / \mathrm{l}=3 \mathrm{ng} / \mathrm{ml}$ ) (Ghorbani and Shafiee-Nick, 2015). Total cholesterol, HDL and LDL levels and atherogenic index contributed to the investigation of lipoprotein profile. Mentioned cholesterols were compared with the reference range (total 2.9-5.0, HDL 1-2.1, LDL 1.2-3.0 mmol/l) valid for the Czech Republic (Methodology of C-peptide..., 2020). Similar methods have been used by Díaz-Ruiz et al. (2019) in the trials describing hydro-carbonated alterations with different fractions of cholesterol.

Lipoprotein values were divided by the $C$-peptide reference range (260-1730 pmol/l) into three subgroups: below, within and above this scale. Cholesterol concentrations had to be relevant for individual $\mathrm{C}$-peptide levels. Atherogenic index contributed to the measurements of lipoprotein fractions with calculations done under the rules: total-HDL/HDL cholesterol (mmol/l). The range was set on the scale: below 3 (optimal), 3-4 (including - lower risk) and above 4 (higher risk of cardiovascular diseases).

\section{Statistical analysis}

Basic statistical parameters were calculated for all groups: number of values $(n)$, arithmetic mean $(\bar{x})$, standard deviation $\left(\mathrm{S}_{\mathrm{X}}\right)$, variance $(\sigma)$, minimum (Max), maximum (Min). Lower whiskers, upper whiskers, quartiles and medians identified data distribution. To test possible association between variables, the Pearson's correlation coefficients $\left(r_{\mathrm{xy}}\right)$ were determined with limits of significance of: $r_{\mathrm{xy}}=0.1-$ low, $r_{\mathrm{xy}}=0.3-$ middle, $r_{\mathrm{xy}}=0.5$ - high. The $F$-test (with quantile $F_{0.975}$ ) was performed to consider the quality of variance and to select the right type of $t$-test. The normality and possible convergence were not limiting because the right types of $t$-test processes mean values were reached in order of tens as normal distribution (central limit theorem) (Zvára and Štěpán, 2002). The level for statistical significance $\left(H_{0}\right.$ vs $\left.H_{\mathrm{a}}\right)$ was set to be at least $0.05>p \geq 0.01$ (significant ${ }^{*}$ ) $0.01>p>0.001$ (moderately significant $\left.^{* *}\right)$ and highly significant ${ }^{* *}(p \leq 0.001)$. 
The calculation of basic data was performed using Microsoft Excel (MS Office - Excel version 16), and this software was also used to prepare the file for subsequent analysis (the exclusion of patients using dietary supplements, the ranges of C-peptide and lipoproteins, glycaemia, insulin). StatPlus (version 7, L.E. 6.9.1.0) provided the information about the data distribution (quartiles, histogram), possible relationships or the differences (the correlations, $F$-test, $t$-test). Software Statistica (version 12) confirmed the statistical results and enabled the graphical process of values. To maintain the quantity and data distribution, the file was not divided by gender and critical values of characteristics were set for both genders and not separately.

\section{Results}

\section{Characteristics of groups}

Statistical characteristics of the groups with various ranges of C-peptide concentrations are shown in Table 1 and Charts 1-5. Comparison of mean values for the groups with various $C$-peptide ranges and the optimal scale is described in Table 2.

Table 1. Statistical characteristics of the groups with various $C$-peptide concentrations

\begin{tabular}{|c|c|c|c|c|c|c|c|c|}
\hline \multicolumn{9}{|c|}{ Individuals with C-peptide concentration $\leq 260 \mathrm{pmol} / 1$} \\
\hline \multirow{2}{*}{ Parameters } & \multirow{2}{*}{ Age (y) } & \multirow{2}{*}{$\begin{array}{l}\text { Glucose } \\
(\mathrm{mmol} / \mathrm{l})\end{array}$} & \multirow{2}{*}{$\begin{array}{l}\text { Insulin } \\
(\mathrm{mIU} / \mathrm{l})\end{array}$} & \multirow{2}{*}{$\begin{array}{l}\text { C-peptide } \\
(\mathrm{pmol} / \mathrm{l})\end{array}$} & \multicolumn{3}{|c|}{ Cholesterols (mmol/l) } & \multirow{2}{*}{$\begin{array}{l}\text { Atherogenic } \\
\text { index }\end{array}$} \\
\hline & & & & & Total & HDL & LDL & \\
\hline$n$ & 111 & 111 & 111 & 111 & 111 & 111 & 111 & 111 \\
\hline $\bar{x}$ & 38.1 & 5.1 & 2.6 & 205.1 & 4.9 & 1.7 & 2.6 & 2.1 \\
\hline$S_{x}$ & 10.8 & 0.5 & 1.1 & 50.1 & 0.9 & 0.5 & 0.7 & 1.0 \\
\hline$\sigma$ & 117.2 & 0.2 & 1.3 & 2513.7 & 0.8 & 0.2 & 0.5 & 0.9 \\
\hline Min & 19 & 3.5 & 0.6 & 29.0 & 2.5 & 0.9 & 1.1 & 0.6 \\
\hline $\operatorname{Max}$ & 70 & 6.5 & 11.8 & 260.0 & 8.1 & 3.7 & 5.1 & 4.8 \\
\hline \multicolumn{9}{|c|}{ Individuals with C-peptide concentration 261-1730 pmol/1 } \\
\hline$n$ & 2952 & 2952 & 2952 & 2952 & 2952 & 2952 & 2952 & 2952 \\
\hline $\bar{x}$ & 40.8 & 5.4 & 10.5 & 764.1 & 5.1 & 1.5 & 3.1 & 2.8 \\
\hline$S_{\mathrm{x}}$ & 11.4 & 0.7 & 47.0 & 322.6 & 1.0 & 0.4 & 0.9 & 1.2 \\
\hline$\sigma$ & 130.8 & 0.5 & 2209.3 & 104084.5 & 1.0 & 0.2 & 0.8 & 1.5 \\
\hline Min & 18 & 3.3 & 2.0 & 263.0 & 2.3 & 0.6 & 0.5 & 0.2 \\
\hline Max & 78 & 18.0 & 2301.0 & 1730.0 & 10.3 & 3.8 & 7.2 & 10.6 \\
\hline \multicolumn{9}{|c|}{ Individuals with $C$-peptide concentration $\geq 1731 \mathrm{pmol} / 1$} \\
\hline$n$ & 126 & 126 & 126 & 126 & 126 & 126 & 126 & 126 \\
\hline $\bar{x}$ & 47.4 & 6.2 & 57.0 & 2674.7 & 5.3 & 1.2 & 3.4 & 3.7 \\
\hline$S_{\mathrm{x}}$ & 10.8 & 1.0 & 85.7 & 1490.9 & 1.1 & 0.4 & 0.9 & 1.3 \\
\hline$\sigma$ & 116.9 & 0.9 & 7340.9 & 2222758.5 & 1.2 & 0.1 & 0.8 & 1.7 \\
\hline Min & 22 & 4.3 & 5.5 & 1740.0 & 3.0 & 0.7 & 1.3 & 1.0 \\
\hline Max & 73 & 10.7 & 331.9 & 6810.0 & 8.7 & 3.1 & 6.1 & 7.1 \\
\hline
\end{tabular}

Table 2. Comparison of mean values for groups with various $C$-peptide ranges

\begin{tabular}{|c|c|c|c|c|c|c|}
\hline \multirow{2}{*}{$\begin{array}{l}\text { C-peptide ranges } \\
(\mathrm{pmol} / \mathrm{l})\end{array}$} & \multirow{2}{*}{ Glucose (mmol/l) } & \multirow{2}{*}{ Insulin (mIU/l) } & \multicolumn{3}{|c|}{ Cholesterols (mmol/l) } & \multirow{2}{*}{ Atherogenic index } \\
\hline & & & Total & HDL & LDL & \\
\hline$\leq 260$ & 5.1 & 2.6 & 4.9 & 1.7 & 2.6 & 2.1 \\
\hline $261-1730$ & 5.4 & 10.5 & 5.1 & 1.5 & 3.1 & 2.8 \\
\hline$\geq 1731$ & 6.2 & 57.0 & 5.3 & 1.2 & 3.4 & 3.7 \\
\hline Optimal range* & $3.9-5.6$ & $2.5-24.0$ & $2.9-5.0$ & $1.0-2.1$ & $1.2-3.0$ & $2.0-3.0$ \\
\hline
\end{tabular}

*Friedecký et al., 2016; Karen et al., 2014; Mathews et al., 1985; Methodology of C-peptide..., 2020. 


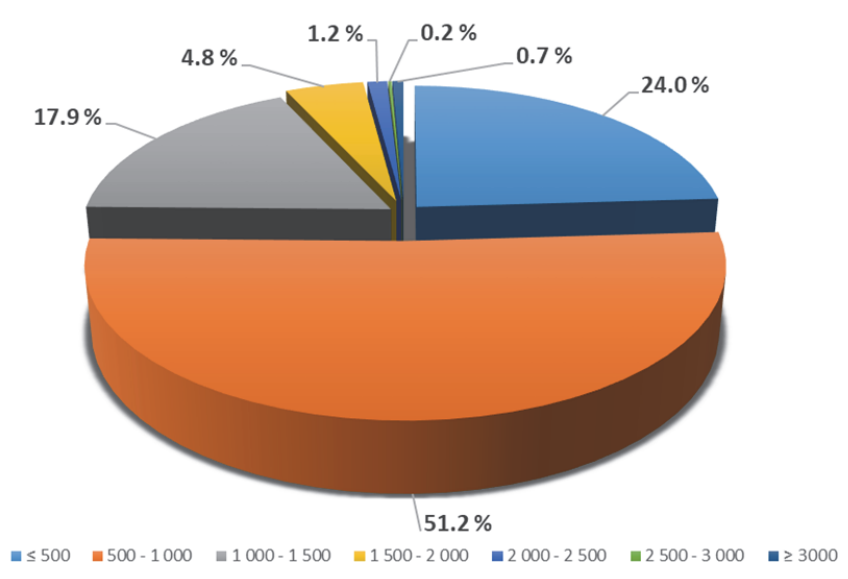

\begin{tabular}{cc}
\hline C-peptide ranges $(\mathrm{pmol} / \mathrm{l})$ & Share $(\%)$ \\
\hline $0-500$ & 24.0 \\
$500-1000$ & 51.2 \\
$1000-1500$ & 17.9 \\
$1500-2000$ & 4.8 \\
$2000-2500$ & 1.2 \\
$2500-3000$ & 0.2 \\
$\geq 3000$ & 0.7 \\
\hline
\end{tabular}

Chart 1. Data distribution of C-peptide in tested file - histogram

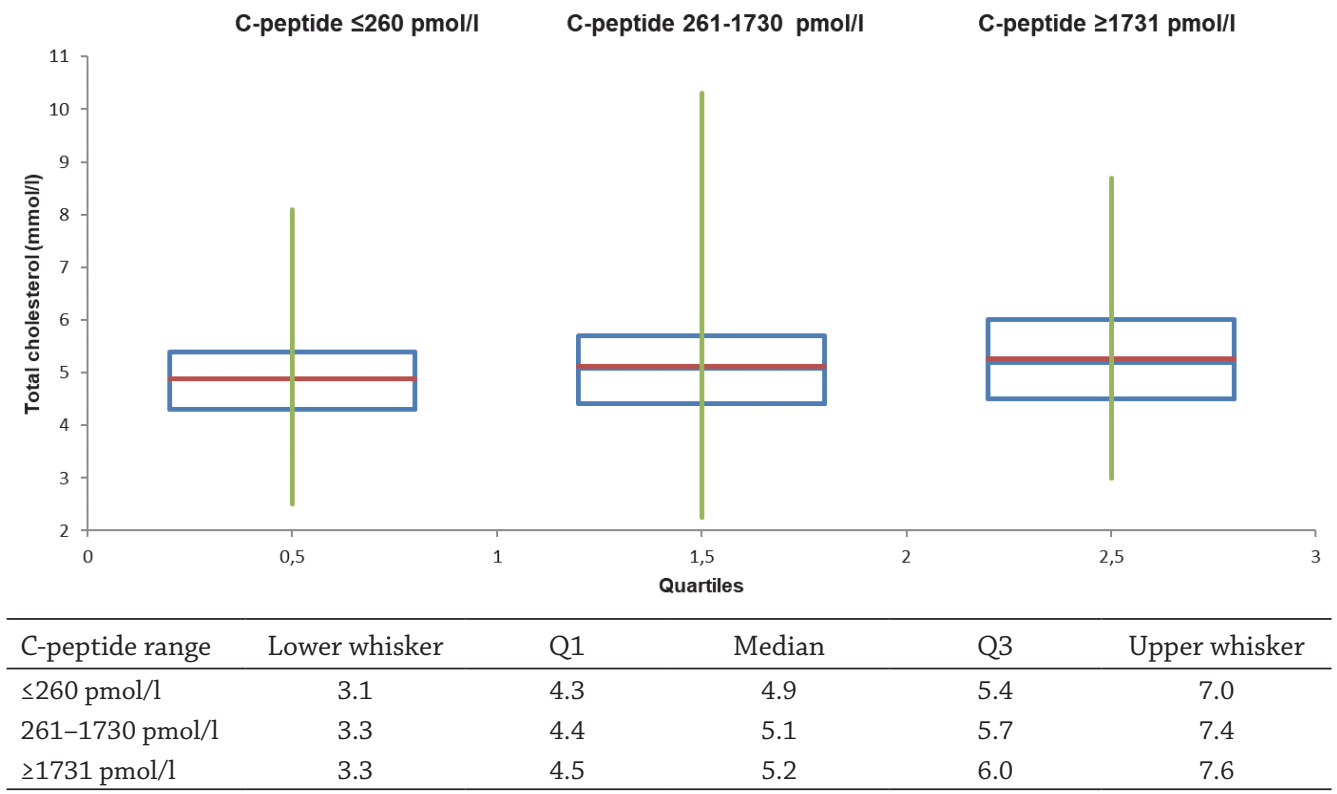

Chart 2. Data distribution of total cholesterol with various ranges of $C$-peptide

Mean glucose concentrations $(5.1,5.4 \mathrm{mmol} / \mathrm{l})$ oscillated under the upper limit of the optimal scale $(5.6 \mathrm{mmol} / \mathrm{l})$ in the groups below and within the reference range of $C$-peptide (261-1730 pmol/l). Naturally, the highest level of glucose (6.2 mmol/l) was reached by the group with a C-peptide concentration above $1731 \mathrm{pmol} / \mathrm{l}$. Insulin showed a similar tendency to that of glucose - and this became higher with increasing C-peptide. Measured insulin (2.6 and $10.5 \mathrm{mIU} / \mathrm{l}$ ) in the groups below and within the reference range of $C$-peptide was lower than the upper limit ( $24 \mathrm{mIU} / \mathrm{l})$. The highest insulin level $(57.0 \mathrm{mIU} / \mathrm{l})$ was analyzed in the group with $\mathrm{C}$-peptide above $1731 \mathrm{pmol} / \mathrm{l}$ and represents more than double the concentration of the optimum (2.5-24.0 mIU/l).

Approximately half of C-peptide concentrations (51.2\%) appeared in the range $500-1000 \mathrm{pmol} / \mathrm{l}$, and almost a quarter of samples (24.0\%) reached concentrations under $500 \mathrm{pmol} / \mathrm{l}$. The individuals with C-peptide levels between 1000 and $1500 \mathrm{pmol} / \mathrm{l}$ formed $17.9 \%$ of all tested subjects. The share of samples rapidly dropped (below 4.8\%) with C-peptide levels above $1500 \mathrm{pmol} / \mathrm{l}$.
As well as glucose, total cholesterol concentrations (4.9, $5.1,5.3 \mathrm{mmol} / \mathrm{l}$ ) fluctuated around the upper limit of the reference range (2.9-5.0 $\mathrm{mmol} / \mathrm{l})$. The changes in total cholesterol have a slight tendency to increase with growing $C$-peptide groups (medians 4.9, 5.1, $5.2 \mathrm{mmol} / \mathrm{l}$ ). Mean values of LDL $(2.6,3.1,3.4 \mathrm{mmol} / \mathrm{l})$ oscillating around the upper limit of the reference range $(3.0 \mathrm{mmol} / \mathrm{l})$ also showed a similar trend. Increasing LDL levels were recorded both in mean values $(2.6,3.1,3.4 \mathrm{mmol} / \mathrm{l})$ and in areas of data (medians 2.5, 3.0, $3.3 \mathrm{mmol} / \mathrm{l}$ ) with higher $\mathrm{C}$-peptide.

HDL was one of the parameters which appeared within the optimal range (1.0-2.1 mmol/l) regardless of the C-peptide scale. Aside from other types of lipoproteins, the concentration of HDL was decreased (1.7, 1.5, $1.2 \mathrm{mmol} / \mathrm{l})$ in comparison to higher $C$-peptide range. Increasing values $(2.1,2.8,3.7)$ of atherogenic index occurred between the groups with lower (below $260 \mathrm{pmol} / \mathrm{l}$ ), optimal and high concentration of C-peptide. Overall, the values of atherogenic index (3.7) exceeded the upper limit (up to 3.0) in the group above the reference $\mathrm{C}$-peptide range. 


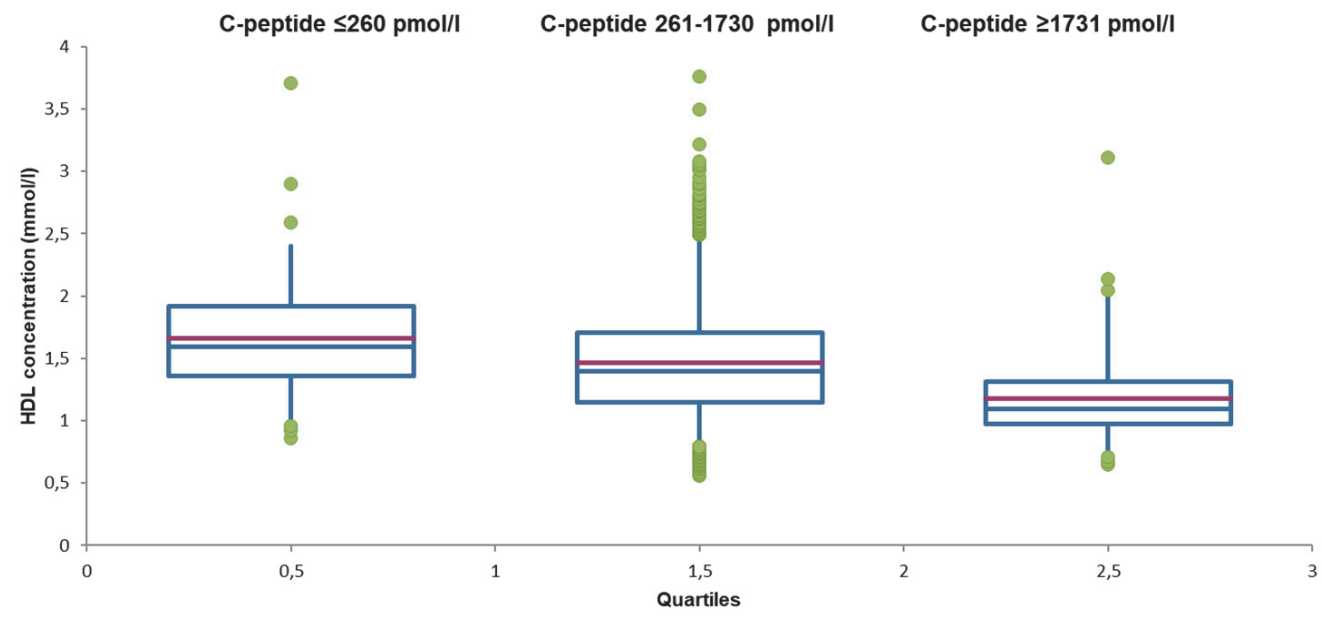

\begin{tabular}{lccccc}
\hline C-peptide range & Lower whisker & Q1 & Median & Q3 & Upper whisker \\
\hline$\leq 260 \mathrm{pmol} / 1$ & 1.0 & 1.4 & 1.6 & 1.9 & 2.6 \\
$261-1730 \mathrm{pmol} / \mathrm{l}$ & 0.8 & 1.2 & 1.4 & 1.7 & 2.5 \\
$\geq 1731 \mathrm{pmol} / \mathrm{l}$ & 0.7 & 1.0 & 1.1 & 1.3 & 2.0 \\
\hline
\end{tabular}

Chart 3. Data distribution of HDL cholesterol with various ranges of $C$-peptide

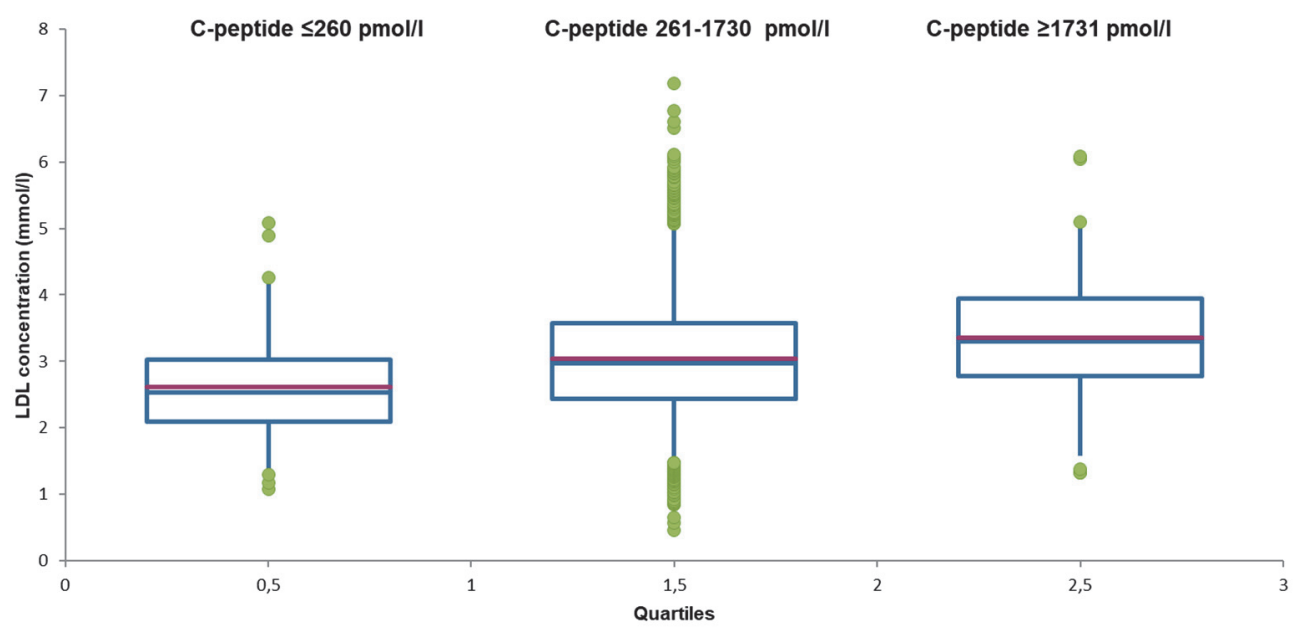

\begin{tabular}{lccccc}
\hline C-peptide range & Lower whisker & Q1 & Median & Q3 & Upper whisker \\
\hline$\leq 260 \mathrm{pmol} / 1$ & 1.3 & 2.1 & 2.5 & 3.0 & 4.2 \\
$261-1730 \mathrm{pmol} / 1$ & 1.5 & 2.4 & 3.0 & 3.6 & 5.1 \\
$\geq 1731 \mathrm{pmol} / 1$ & 1.5 & 2.8 & 3.3 & 4.0 & 5.1 \\
\hline
\end{tabular}

Chart 4. Data distribution of LDL cholesterol with various ranges of C-peptide 


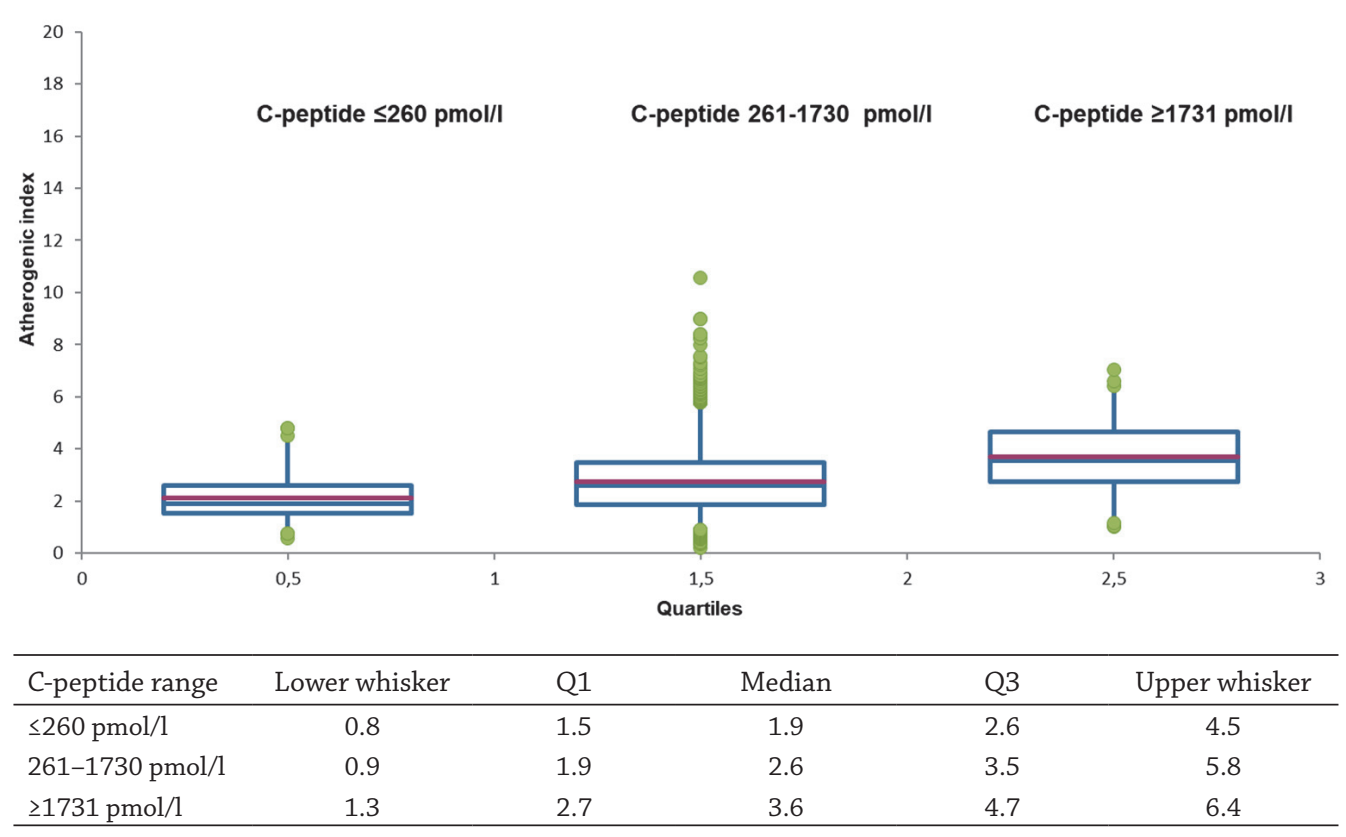

Chart 5. Data distribution of atherogenic index with various ranges of $C$-peptide

\section{Statistical analysis}

To test possible correlations between C-peptide and lipoprotein parameters, the Pearson's correlation coefficients $\left(r_{\mathrm{xy}}\right)$ were determined (Table 3 ).

Table 3. Correlations between C-peptide and cholesterols

\begin{tabular}{lcccc}
\hline $\begin{array}{l}\text { Pearson's } \\
\text { correlation } \\
\begin{array}{l}\text { coefficients } \\
\left(r_{\text {xy }}\right)\end{array}\end{array}$ & $\begin{array}{c}\text { Total } \\
\text { cholesterol } \\
(\mathrm{mmol} / \mathrm{l})\end{array}$ & $\begin{array}{c}\text { HDL } \\
\text { cholesterol } \\
(\mathrm{mmol} / \mathrm{l})\end{array}$ & $\begin{array}{c}\text { LDL } \\
\text { cholesterol } \\
(\mathrm{mmol} / \mathrm{l})\end{array}$ & $\begin{array}{c}\text { Atherogenic } \\
\text { index }\end{array}$ \\
\hline $\begin{array}{l}\text { C-peptide } \\
(\mathrm{pmol} / \mathrm{l})\end{array}$ & 0.04 & -0.36 & 0.17 & 0.36 \\
\hline
\end{tabular}

A negative correlation $\left(r_{\mathrm{xy}}=-0.36\right)$ was found between C-peptide and HDL concentrations. A similar relationship, but with an opposite trend, was recorded between $C$-peptide and atherogenic index $\left(r_{\mathrm{xy}}=0.36\right)$. Other correlations (C-peptides, total and LDL cholesterols) seemed to be non-significant $\left(r_{\mathrm{xy}}=\right.$ $0.04,0.17)$. Subsequent regression analysis was not evaluated due to lower results of correlation coefficients (up to 0.5).

The $F$-test was used to determine the equality of variance between the groups with different $C$-peptide ranges (Table 4).

Table 4. Results of F-test/critical values between lipoproteins at different ranges of C-peptide (pmol/l)

\begin{tabular}{|c|c|c|c|}
\hline \multirow{2}{*}{$F$-test result/critical value } & \multicolumn{3}{|c|}{ Total cholesterol (mmol/1) } \\
\hline & C-peptide $\leq 260$ & C-peptide 261-1730 & C-peptide $\geq 1731$ \\
\hline C-peptide $\leq 260$ & - & $0.85 * / 0.79$ & $0.71 / 0.74$ \\
\hline C-peptide $261-1730$ & $0.85 * / 0.79$ & - & $0.83^{*} / 0.82$ \\
\hline \multirow{2}{*}{ F-test result/critical value } & \multicolumn{3}{|c|}{ HDL cholesterol (mmol/l) } \\
\hline & C-peptide $\leq 260$ & C-peptide 261-1730 & C-peptide $\geq 1731$ \\
\hline C-peptide $\leq 260$ & - & $1.12 / 1.24$ & $1.69 * / 1.35$ \\
\hline C-peptide 261-1730 & $1.12 / 1.24$ & - & $1.51^{*} / 1.25$ \\
\hline \multirow{2}{*}{$F$-test result/critical value } & \multicolumn{3}{|c|}{ LDL cholesterol (mmol/1) } \\
\hline & C-peptide $\leq 260$ & C-peptide 261-1730 & C-peptide $\geq 1731$ \\
\hline C-peptide $\leq 260$ & - & $0.67 / 0.79$ & $0.61 / 0.74$ \\
\hline C-peptide 261-1730 & $0.67 / 0.79$ & - & $0.91 * / 0.82$ \\
\hline \multirow{2}{*}{$F$-test result/critical value } & \multicolumn{3}{|c|}{ Atherogenic index } \\
\hline & C-peptide $\leq 260$ & C-peptide 261-1730 & C-peptide $\geq 1731$ \\
\hline C-peptide $\leq 260$ & - & $0.61 / 0.79$ & $0.54 / 0.74$ \\
\hline C-peptide 261-1730 & $0.61 / 0.79$ & - & $0.88 * / 0.82$ \\
\hline
\end{tabular}


The variances of total, HDL, LDL and atherogenic index showed statistically significant differences $(p<0.05)$ between the optimal range (261-1730 pmol/l) and higher level of C-peptides ( $\geq 1731 \mathrm{pmol} / \mathrm{l})$. The variances of HDL also differed between non-physiological groups of $C$-peptide range ( $\leq 260 \mathrm{pmol} / \mathrm{l}$ and $\geq 1731 \mathrm{pmol} / \mathrm{l})$. In the case of total cho- lesterol, the variances seemed to be statistically significant between lower limit $(\leq 260 \mathrm{pmol} / \mathrm{l})$ and the reference range (261-1730 pmol/1) of C-peptide.

Based on the F-test results, the right type of $t$-test was determined to compare lipoprotein values within the groups with different $C$-peptide concentration ranges (Table 5).

Table 5. Results of $t$-test/critical values between lipoproteins at different range of C-peptide (pmol/l)

\begin{tabular}{|c|c|c|c|}
\hline \multirow{2}{*}{$t$-test result/critical value } & \multicolumn{3}{|c|}{ Total cholesterol (mmol/l) } \\
\hline & C-peptide $\leq 260$ & C-peptide 261-1730 & C-peptide $\geq 1731$ \\
\hline C-peptide $\leq 260$ & - & $2.97^{* *} / 1.97$ & $3.23^{* *} / 1.97$ \\
\hline C-peptide $261-1730$ & $2.97^{* *} / 1.97$ & - & $1.95 / 1.97$ \\
\hline \multirow{2}{*}{$t$-test result/critical value } & \multicolumn{3}{|c|}{ HDL cholesterol (mmol/1) } \\
\hline & C-peptide $\leq 260$ & C-peptide 261-1730 & C-peptide $\geq 1731$ \\
\hline C-peptide $\leq 260$ & - & $3.61^{* *} / 1.96$ & $8.32^{* * *} / 1.98$ \\
\hline C-peptide 261-1730 & $3.61^{* *} / 1.96$ & - & $7.54^{* * *} / 1.98$ \\
\hline \multirow{2}{*}{$t$-test result/critical value } & \multicolumn{3}{|c|}{ LDL cholesterol (mmol/l) } \\
\hline & C-peptide $\leq 260$ & C-peptide 261-1730 & C-peptide $\geq 1731$ \\
\hline C-peptide $\leq 260$ & - & $5.75^{* * *} / 1.96$ & $7.36^{* * *} / 1.97$ \\
\hline C-peptide $261-1730$ & $5.75^{* * *} / 1.96$ & - & $4.34^{* * *} / 1.97$ \\
\hline \multirow{2}{*}{$t$-test result/critical value } & \multicolumn{3}{|c|}{ Atherogenic index } \\
\hline & C-peptide $\leq 260$ & C-peptide 261-1730 & C-peptide $\geq 1731$ \\
\hline C-peptide $\leq 260$ & - & $5.91^{* * *} / 1.96$ & $11.02^{* * *} / 1.97$ \\
\hline C-peptide $261-1730$ & $5.91^{* * *} / 1.96$ & - & $8.61^{* * *} / 1.98$ \\
\hline
\end{tabular}

The mean values of lipoproteins (HDL, LDL and atherogenic index) at different $C$-peptide concentrations showed statistically significant changes $(p \leq 0.001)$, especially between the groups below and above the reference range (261-1730 $\mathrm{pmol} / \mathrm{l})$.

Similar statistical results with high significance $(p \leq 0.001)$ appeared between HDL, LDL and atherogenic index in the groups above $(\geq 1731 \mathrm{pmol} / \mathrm{l})$ and within the reference range (261-1730 pmol/l) of C-peptide. The LDL and atherogenic index reached significant differences $(p \leq 0.001)$ not only by comparing the values with the $C$-peptide reference scale, but also inside and outside of it.

\section{Discussion}

The parameters of glycaemia in tested samples (glucose $5.4 \mathrm{mmol} / \mathrm{l}$, insulin $10.5 \mathrm{mIU} / \mathrm{l}$ ) occurring within the range of C-peptide (261-1730 pmol/l) correspond with the results of non-diabetic patients (glucose $5.43 \mathrm{mmol} / \mathrm{l}$, insulin $9.13 \mathrm{mIU} / \mathrm{l})$ in the Czech Republic for the year 2018. Equally, the values of total, HDL and LDL cholesterols (5.1, 1.5 and $3.1 \mathrm{mmol} / \mathrm{l}$ ) within the reference range of $C$-peptide approached the mean values in glucose tolerant patients (5.11, 1.46, $3.02 \mathrm{mmol} / \mathrm{l}$ ) in the same study (Horáková et al., 2019).

The correlation between the $C$-peptide fasting serum, HDL and triglyceride level $(p<0.001)$ has already been recorded in the trials since 1983. Multiple regressions provided by Garcia-Webb et al. (1983) discovered that the association between C-peptide and HDL cholesterol was a consequence of interrelated associations between $C$-peptide, triglycerides and choles- terols. The tests of insulin parameters and serum lipid in the trial of Walton et al. (1995) also showed that fractions of HDL (HDL 2) in healthy men positively correlated with C-peptide levels.

However, mutual relationship between fractions of lipoproteins and glycaemia has been found in an opposite tendency too. Negative correlation appeared between C-peptide (as markers of insulin resistance) and HDL concentrations in the Brazilian cohort study (Andrade et al., 2018). The tests of logistic regression in non-diabetic participants also confirmed a strong negative association between the levels of $C$-peptide and HDL $(p<0.001)$. The analysis of data distribution determined that the values of second, third and fourth quartile were linked with the gradual reduction of HDL in serum ( $\mathrm{Li}$ et al., 2015). Although a causality of the observations remains unclear, high values of C-peptide and low HDL levels were also discovered by Patel et al. (2012) in a USA retrospective study in glucose tolerant patients.

Regarding the results of this trial and some authors' conclusions, it is possible to recommend $\mathrm{C}$-peptide as a signal of lipoprotein metabolism changes and to consider this as significant for other cardiovascular disease investigations (Min and Min, 2013; Pickens et al., 2016).

\section{Conclusions}

The evaluations of glycaemia parameters have recently expanded to other metabolic assessments of lipoproteins, triglycerides, thyroid hormones or cardiovascular system functions. These results suggest the importance of what type of 
lipoprotein parameter should be linked to the relationship with glycaemia metabolism. The $\mathrm{C}$-peptide reference range of 260-1730 pmol/1 has been determined as a relevant factor for possible alterations of cholesterol fractions. Based on these conclusions, the C-peptide is relevant - not only as a parameter of insulin secretion - but also as a useful indicator of lipoprotein changes during the development of metabolic syndrome and the atherogenesis.

\section{Ethical aspects and conflict of interests}

The authors have no conflict of interests to declare.

\section{Funding}

This work was supported by NAZV-QK 1910174.

\section{References}

Andrade RLM, Gigante DP, de Oliveira IO, Horta BL (2018). C-Peptide and cardiovascular risk factors among young adults in a southern Brazilian Cohort. BMC Endocr Disord 18: 80. DOI: 10.1186/s12902-018-0308-5.

Bo S, Gentile L, Castiglione A, Prandi V, Canil S, Ghigo E, Giccone G (2012). C-peptide and the risk for incident complications and mortality in type 2 diabetic patients: a retrospective cohort study after a 14-year follow-up. Eur J Endocrinol 167(2): 173-180. DOI: 10.1530/EJE-12-0085.

Díaz-Ruiz M, Martínez-Triguero ML, López-Ruiz A, Fernándezde la Cruz F, Bañuls C, Hernández-Mijares A (2019). Metabolic disorders and inflammation are associated with familial combined hyperlipemia. Clin Chim Acta 490: 194-199. DOI: 10.1016/j. cca.2018.09.009.

Friedecký B, Kratochvíla J, Springer D, Prázný M, Pelikánová T, Zima T, Racek J (2016). Diabetes mellitus - laboratorní diagnostika a sledování stavu pacientů [Diabetes mellitus laboratory diagnosis and monitoring of patients]. Klin Biochem Metab 24: 32-47.

Garcia-Webb P, Bonser AM, Whiting D, Masarei JRL (1983). Insulin resistance a risk factor for coronary heart disease? Scan J Clin Lab Invest 43(8): 677-685. DOI: 10.1080/00365518309168849.

Ghorbani A, Shafiee-Nick R (2015). Pathological consequences of $C$-peptide deficiency in insulin-dependent diabetes mellitus. World J Diabetes 6(1): 145-150. DOI:10.4239/wjd.v6.i1.145.

Harnishsingh B, Rama B (2018). Is C-peptide a predictor of severity of coronary artery disease in metabolic syndrome? An observational study. Indian Heart J 70(Suppl. 3): S105-S109. DOI: 10.1016/j.ihj.2018.07.005.

Hirai FE, Moss SE, Klein BE, Klein R (2008). Relationship of glycemic control, exogenous insulin and C-peptide levels to ischemic heart disease mortality over a 16-year period in people with older-onset diabetes. Diabetes Care 31(3): 493-497. DOI: 10.2337/dc07-1161.

Horáková D, Štěpánek L, Janout V, Janoutová J, Pastucha D, Kollárová H, et al. (2019). Optimal homeostasis model assessment of insulin resistance (HOMA-IR) cut off in Czech population. Medicina (Kaunas) 55(5): 158. DOI: 10.3390/medicina55050158.

Jones AG, Hattersley AT (2013). The clinical utility of C-peptide measurement in the care of patients with diabetes. Diabet Med 30(7): 803-817. DOI: 10.1111/dme.12159.
Karen I, Svačina Š, et al. (2014). Diabetes mellitus v primární péči [Diabetes mellitus in primary care], 2nd ed. Prague: Axonite.

Khan HA, Sobki SH, Ekhzaimy A, Khan I, Almusawi MA (2018). Biomarker potential of $C$-peptide for screening of insulin resistance in diabetic and non-diabetic individuals. Saudi J Biol Sci 25(8): 1729-1732. DOI: 10.1016/j.sjbs.2018.05.027.

Kulkarni CM, Patil S (2016). Urinary C-peptide and urine C-peptide/creatinine ratio (UCPCR) are possible predictors of endogenous insulin secretion in T2DM subjects - a randomized study. Int J Pharm Bio Sci 7: 443-446. DOI: 10.22376/ ijpbs.2016.7.4.b443-446.

Leighton E, Sainsbury CA, Jones GC (2017). A Practical review of C-Peptide testing in diabetes. Diabetes Ther 8(3): 475-487. DOI: 10.1007/s13300-017-0265-4.

Li Y, Li Y, Meng L, Zheng L (2015). Association between serum $C$-peptide as a risk factor for cardiovascular disease and highdensity lipoprotein cholesterol levels in nondiabetic individuals. PLoS One 10(1): e112281. DOI: 10.1371/journal.pone.0112281.

Matthews DR, Hosker JP, Rudenski AS, Naylor BA, Treacher DF, Turner RC (1985). Homeostasis model assessment: insulin resistance and beta-cell function from fasting plasma glucose and insulin concentrations in man. Diabetologia 28(7): 412-419. DOI: 10.1007/BF00280883.

Methodology of C-peptide, glucose, total, HDL and LDL cholesterol (2020). Department of Clinical Biochemistry and Diagnostics, University Hospital Hradec Králové. [online] [cit. 2020-07-15]. Available at: http://ukbd.fnhk.cz/seznam-metod.html

Min J-Y, Min K-B (2013). Serum C-peptide levels and risk of death among adults without diabetes mellitus. Can Med Assoc J 185(9): E402-408. DOI: 10.1503/cmaj.121950.

Patel N, Taveira TH, Choudhary G, Whitlatch H, Wu W-C (2012). Fasting serum $C$-peptide levels predict cardiovascular and overall death in nondiabetic adults. J Am Heart Assoc 1(6): e003152. DOI: 10.1161/JAHA.112.003152.

Pickens CA, Matsuo KH, Fenton JI (2016). Relationship between body mass index, C-Peptide, and delta-5-desaturase enzyme activity estimates in adult males. PLoS One 11(3): e0149305. DOI: 10.1371/journal.pone.0149305.

Pozzan R, Dimetz T, Gazzola HM, Gomes MB (1997). The C-peptide response to a standard mixed meal in a group of Brazilian type 1 diabetic patients. Braz J Med Biol Res 30(10): 1169-1174. DOI: 10.1590/S0100-879X1997001000005.

Rebsomen L, Khammar A, Raccah D, Tsimaratos M (2008). C-peptide effects on renal physiology and diabetes. Exp Diabetes Res 2008: 281536. DOI: $10.1155 / 2008 / 281536$.

Wahab N, Chen R, Curb JD, Bradley J, Willcox BJ, Rodriguez BL (2018). The association of fasting glucose, insulin and C-peptide with 19-year incidence of coronary heart disease in older Japanese-American men; the Honolulu Heart Program. Geriatrics (Basel) 3(2): 22. DOI: 10.3390/geriatrics3020022.

Walton C, Lees B, Crook D, Godsland IF, Stevenson JC (1995). Relationships between insulin metabolism, serum lipid profile, body fat distribution and blood pressure in healthy men. Atherosclerosis 118(1): 35-43. DOI: 10.1016/00219150(95)05590-s.

Yosten GLC, Maric-Bilkan C, Luppi P, Wahren, J (2014). Physiological effects and therapeutic potential of proinsulin C-peptide. Am J Physiol Endocrinol Metab 307(11): 955-968. DOI: 10.1152/ ajpendo.00130.2014.

Zvára K, Štěpán J (2002). Pravděpodobnost a matematická statistika [The probability and mathematical statistics], 3rd ed. Prague: Matfyzpress. 